\title{
Geotourism in the Salesópolis-Caraguatatuba Trail, São Paulo, Brazil: A Possibility to Utilize Geological Elements for Sustainable Development
}

\author{
Victor F. Velázquez ${ }^{1}$, José M. Azevedo Sobrinho ${ }^{2}$, Mikhaela A. J. S. Pletsch ${ }^{1}$, Antonio C. M. Guedes ${ }^{2}$, \\ Gibby Zobel ${ }^{3}$ \\ ${ }^{1}$ Escola de Artes, Ciências e Humanidades, Universidade de São Paulo, São Paulo, Brasil; ${ }^{2}$ Instituto Geológico, Secretaria do Meio \\ Ambiente do Estado de São Paulo, São Paulo, Brasil; ${ }^{3}$ British Broadcasting Corporation, London, England. \\ Email:vvf@usp.br
}

Received July $17^{\text {th }}$, 2013; revised August $19^{\text {th }}, 2013$; accepted September $16^{\text {th }}, 2013$

Copyright (C 2013 Victor F. Velázquez et al. This is an open access article distributed under the Creative Commons Attribution License, which permits unrestricted use, distribution, and reproduction in any medium, provided the original work is properly cited.

\begin{abstract}
The Salesópolis-Caraguatatuba trail lies slightly more than $130 \mathrm{~km}$ to ESE from the São Paulo city, and it is fully inserted within the Atlantic Forest. The region is particularly interesting because it brings together a complex lithological association and an exuberant topographical expression. A set of geological and geomorphological elements with high potentiality for the sustainable tourism development is documented in this paper. The geosites provide a wide variety of attraction, including valleys, streams, waterfalls and the unusual shapes of rocks. In each one of those outcrops, the visitors will have an exceptional opportunity for a better understanding about the processes that control the landscape evolution. In accordance with the new conception of geotourism, and taking as a basis the concepts of the geoscience for a rereading and interpretation of the several aspects of space and landscape, the sites catalogued should enable a new insight to increase environmental awareness of the local community, and, mainly, to encourage an innovative form of economic activity that has as a fundamental principle the nature preservation.
\end{abstract}

Keywords: Salesópolis-Caraguatatuba Trail; Geotourism; Geosite; Nature Preservation

\section{Introduction}

The success of an initiative that aims to give support to the programs of environmental and territorial planning must necessarily take into account the close relationship between preservation and sustainable development. The ecotourism has often been quoted as a form of tourism that has as a fundamental principle the nature preservation. Although a lot more recent, the geotourism is also another tourism activity that has become increasingly popular in different sectors of the society. According to Dowling [1], geotourism is a new global phenomenon of nature tourism firmly founded in the diversity of the geological features. Since its introduction in 1995 by the geologist Tomas A. Hose [2], and as normally occurs with any other new terms, numerous definitions have been proposed for geotourism. In order to avoid ambiguous concepts, in this paper was adopted the definition proposed by Newsome and Dowling [3] and Newsome et al. [4], where these authors postulate: "geotourism is a form of natural area tourism that specifically focuses on geology and landscape. It promotes tourism to geosites and the conservation of geodiversity and an understanding of earth sciences through appreciation and learning. This is achieved through independent visits to geological features, use of geotrails and view points, guided tours, geoactivities and patronage of geosite visitor centres". It should be noted that, unlike the other forms of tourism, here the main focus of the visits is to explore the geological and geomorphological features of the region.

Regarding the Salesópolis-Caraguatatuba trail (SCT), some of the attractions that the visitors may find along the course are spring-fed streams, rivers, waterfalls, extraordinary rock exposures, prominent relief and a lush vegetation of the Atlantic Forest [5]. Given the existence of an incipient informal tourism throughout the region, it is of great importance the implementation of a geotourism program of effective policies sustainable development that, besides allowing to the visitors a direct contact with the nature, transmits in a simple and pleasurable 
way the fundamental concepts for understanding and valuing the geological components that conform the landscapes. This paper draws on a recent field expedition, which has made possible to catalogue a number of geosites with high potentiality for sustainable tourism, education and landscape photography. Each one of these outcrops offers a particular attraction. Some are characterised by the lithological association, others reveal a close relation between shape and geological processes, as well as the occurrence of a large area of weathering that illustrates in a clear manner the process of soil formation.

\section{Geographical Location}

The SCT is an unpaved road denominated by the São Paulo Mountain Bike Tourism like "Petrobrás Road". With a high sinuosity, sharp curves and steep hillsides, the track begins at the crossing with the Pedro Eroles Highway, SP-88, in Salesópolis, and extending for 75 km up to its intersection with the Rio-Santos Highway, BR101, in Caraguatatuba (Figure 1). The trail is fully in- serted inside the Atlantic Forest, important biome that comprises several native species of flora and fauna [6].

\section{Geological Setting}

With an extension of approximately $1500 \mathrm{~km}$, the Ribeira Belt accompanies the Atlantic coast of the Brazilian southeastern region, and it represents an important episode of a complex long-term crustal evolution that occurred during the final accretion of the Western Gondwana supercontinent [7-9]. The Ribeira Belt displays a very complex orogenic zone composed of several geological units and has received a large number of proposals for their lithostratigraphical division. According to Tassinari et al. [10], the major lithological associations of the central segment, located in the south-eastern margin of the São Paulo State, can be grouped in three main domains: São Roque, Embú and Costeiro.

The lithological units that occur along the SCT correspond to the Ribeira Belt central segment, Costeiro domain, and are constituted in largely part of gneissic and

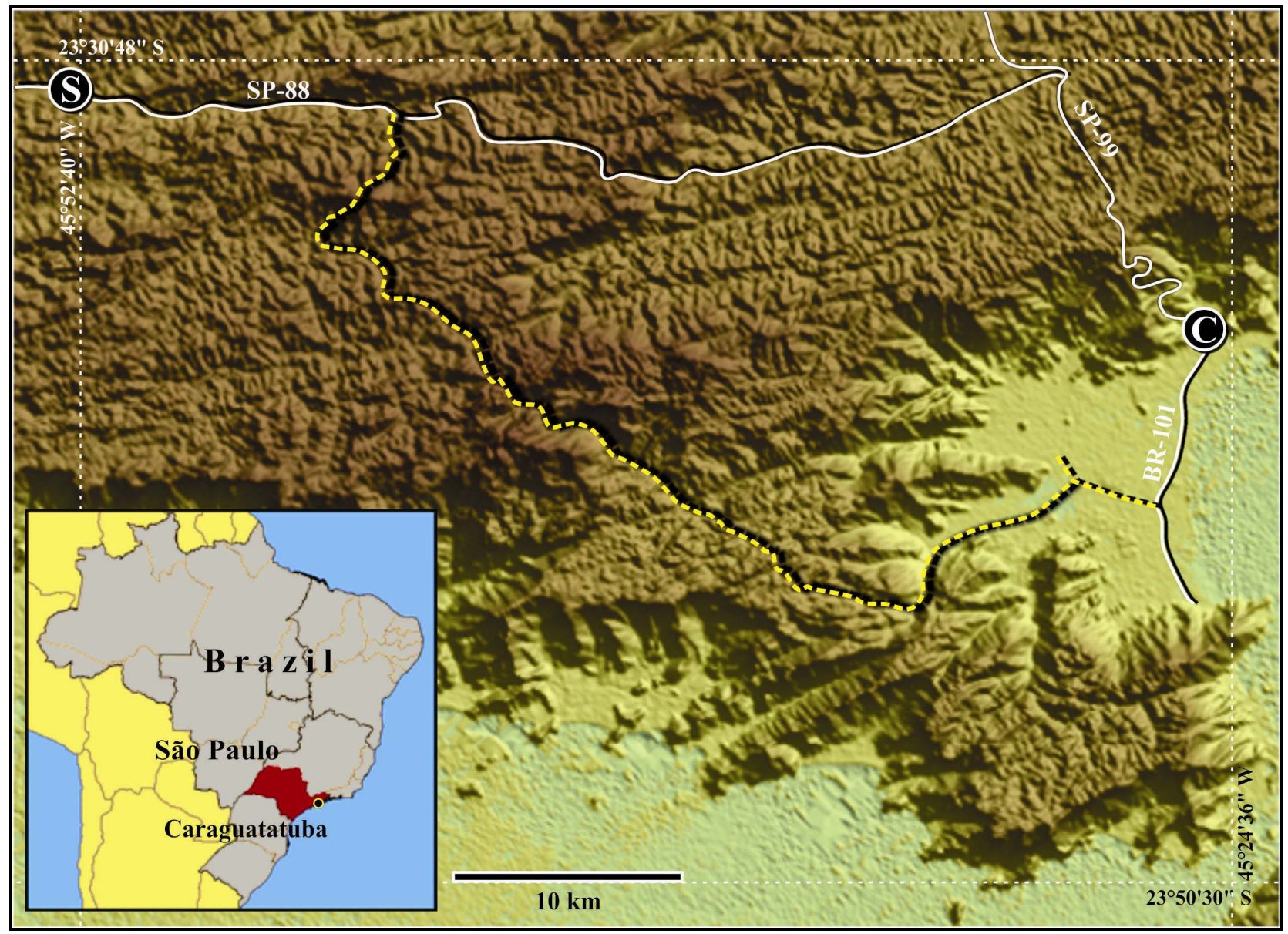

Figure 1. The map illustrates the intersection of the SCT (dashed yellow line) with the Pedro Eroles Highway, SP-88, culminating at the Rio-Santos Highway, BR-101. The letters S and C indicate the localities of Salesópolis and Caraguatatuba, respectively. Digital elevation model generated from the SRTM data (IUGS). 
granitoid rocks [11] (Figure 2). In the extreme south of the area, the rocks belonging to the Banded Gneiss Unit show several superimposed tectonic deformations, development of intense mylonitic foliation, and a pervasive segregation of light and darks minerals, resulting in a complex relationship between texture and structure [12, 13]. The Migmatitic Granite Gneiss Unit has a larger occurrence than the previous unit. Under this denomination, Perrota et al. [14] describe a set of rocks of granitic composition that present strong foliation, marked banding and diverse other migmatitic structures (mainly nebulitic, shlieren and stromatitic). As a textural variation, k-feldspar augen gneiss can locally occur [15]. All of these rocks are invariably constituted of quartz, microcline, plagioclase, biotite and amphibole [16]. The rocks of the Peraluminous Gneisses Unit outcrop in the northern and southern sectors of the trail. Paragneiss, kinzigitic gneiss, exhibiting marked gneissic banding as main metamorphic structure, and minor tabular bodies of amphibolite predominate in this unit [13]. In the northern sector of the trail, there is an extensive exposition of the
Orthogneiss Unit. The massive and heterogeneous occurrence of structures such as nebulitic, shlieren and stromatitic confer it to those rocks a noticeable magmatitic character. Veins and segregations of light colored granitic composition and, to a lesser extent, thin layers of amphibolite may be associated with this unit $[17,18]$. The central part consists of a long strip formed by the Foliated Calc-alkaline Granite Unit. Here are usually reported an association of diverse types of granitic rocks, mediumto course-grained, often porphyritic and markedly foliated, composed of microcline (much as megacrysts), quartz and biotite [19,20]. The Mafic Suite occupies a small area in the southern sector of the trail. Dias Neto et al. [21] interpret this occurrence as a late- to post-orogenic intrusion, constituted mainly of metagabro, metadiorite and porphyritic microdiorite.

Additionally, detrital deposits are broadly distributed throughout the coast line and in the valleys. The thickness of these heterogeneous deposits of unconsolidated sediments is strongly controlled by the local variation of the topographic gradient, and the layers are usually formed,

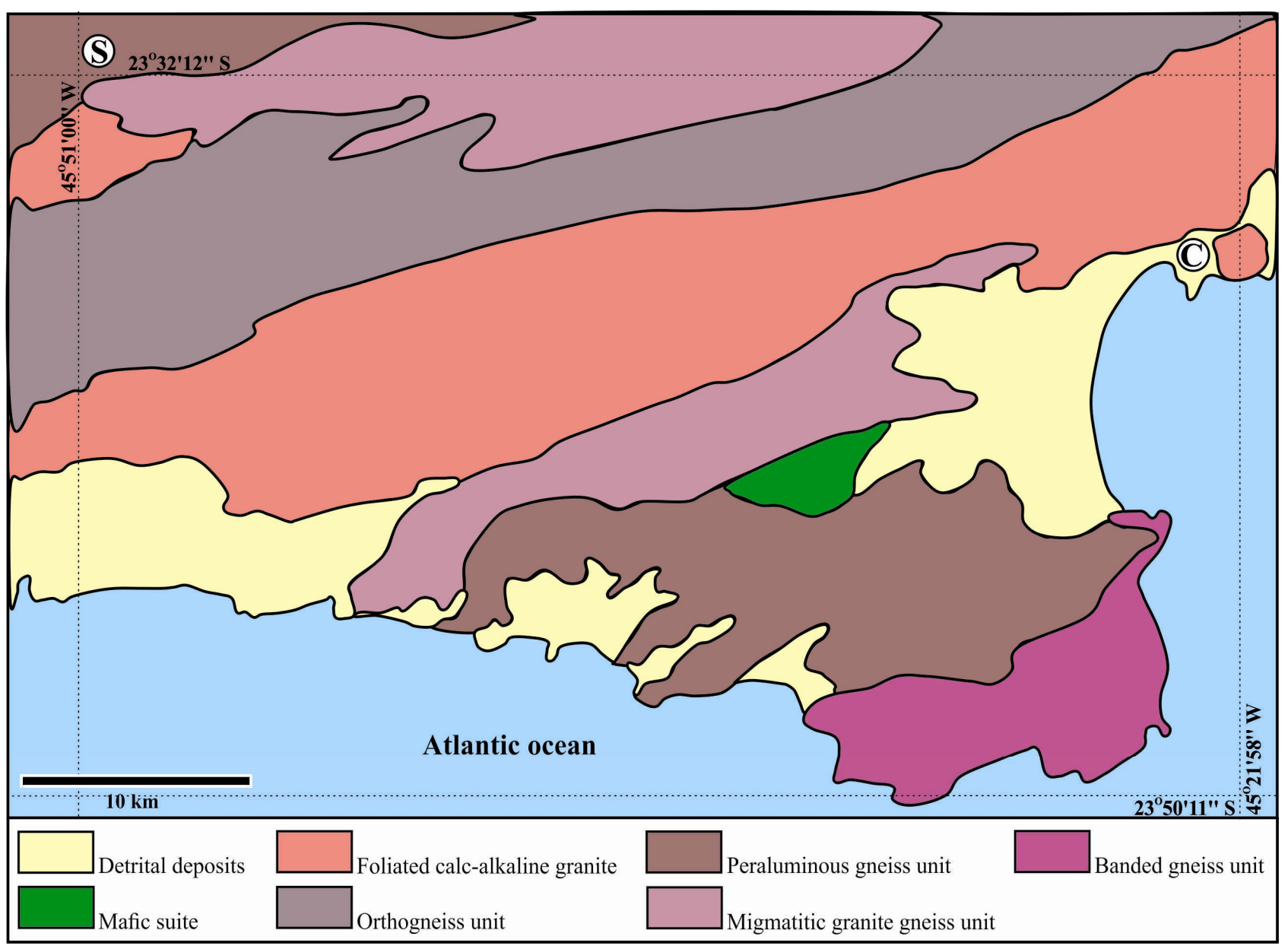

Figure 2. Simplified geological map of the SCT region (extracted from Perrota et al. [14]). The letters S and C as in Figure 1. 
in varying proportions, by gravel, sand, silt and clay.

\section{Geomorphological Aspect}

The Serra do Mar is a set of long steep slope that extends for approximately $1000 \mathrm{~km}$ from the northern region of the Santa Catarina State until the Rio de Janeiro State and represents the most prominent relief of the southeastern Brazil continental margin [22,23]. In the São Paulo State, the Serra do Mar is traditionally included in the Costeira Geomorphological Province [24] and separated into three regions: southern, central and northern (Figure 3). In morphostructural terms, the northern region is characterised by the occurrence of a series of expressive fault escarpment, major lineaments and curvilinear features (mainly topolineaments), with a NE-SW preferential direction $[25,26]$. These structures exert a particularly strong influence on the surface drainage patterns. Locally, it is possible to recognize, from E toward W, four main morphological domains (Figure 4): coast plain, Juqueriquerê Plateau, Lorenço Velho Plateau and Morais Plateau [20]. Excepting the coastal plain, which is separated at its far south-western of the Juqueriquerê Plateau by an abrupt scarp erosion of very irregular outline, all other domains are strongly controlled by the crystalline basement rocks and regional tectonic frameworks, displaying a set of elongated ridges arranged, in most cases, in the NE-SW direction and usually separated by large depressions. Deep valleys in "V" shape, steep slopes and dissected, as well as alignments of hills with the tops flattened, which sustain different altitudes, are the main morphological elements. These landform patterns have been interpreted for some authors as indicative records of several diachronic events that occurred during the Cretaceous-Tertiary, with intense tectonic activity, uplifting and denudation process, resulting in the reactivation of oldest shear zones and consequent geomorphological compartments of the current landscape [27-29].

\section{Potential Sites for Geotourism}

The complex geological and geomorphological history of the region provides a number of favourable sites for the geotourism activity. However, the sites selection is not an easy task. On the one hand, the difficulty has its origin in the own geological complexity and, on the other hand, the vast majority of the people dealing with tourism do not has the sufficient knowledge for an analysis and valorisation of geosites. As pointed out by Predrag and Mirela [30], this deadlock situation has direct implication in the assessment criteria: "principles of tourist valorisation are different from principles of distinguishing geodiversity

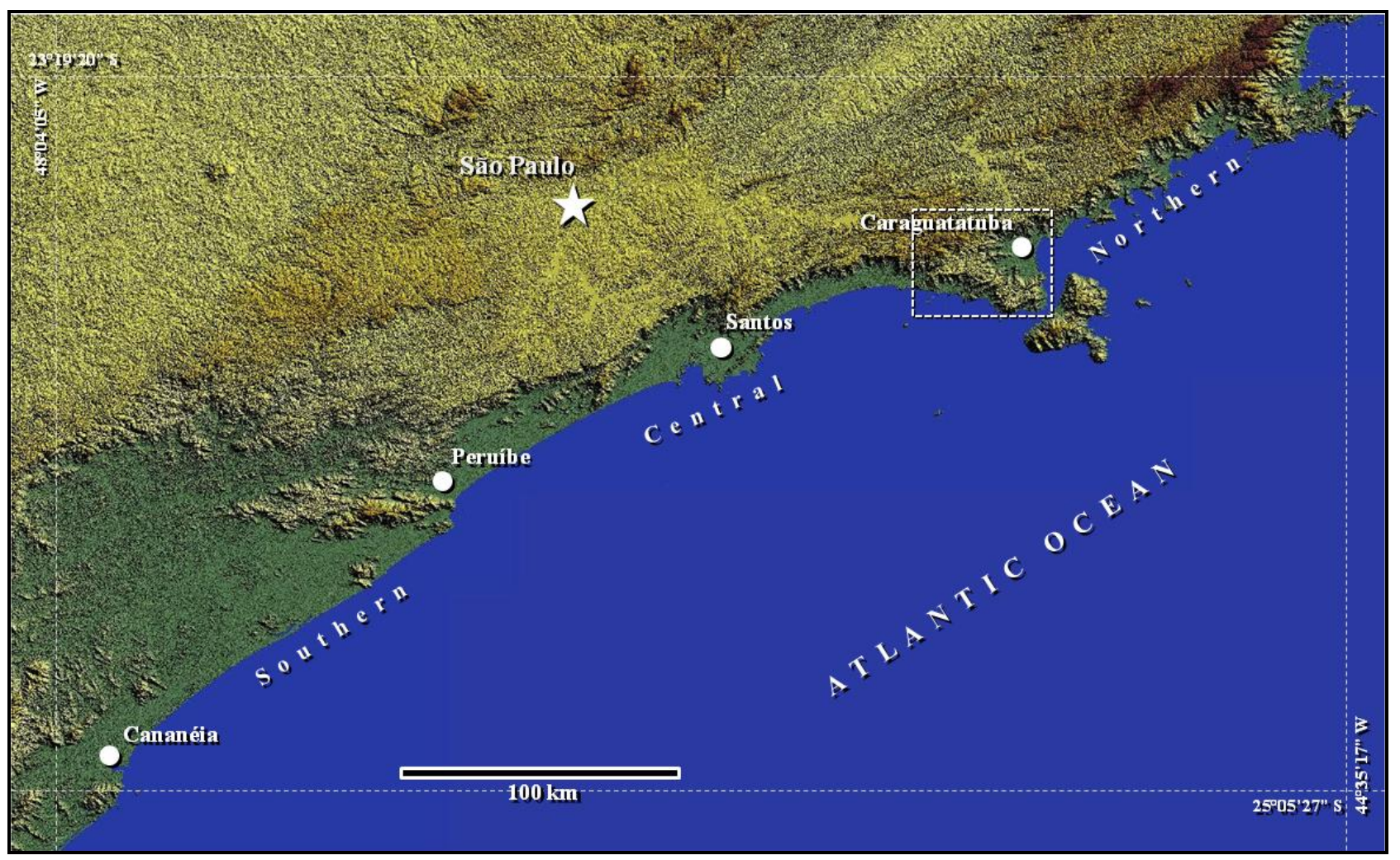

Figure 3. Location of the SCT (dashed box) in the Costeira Geomorphological Province of the Serra do Mar. Digital elevation model generated from the SRTM data (IUGS). 


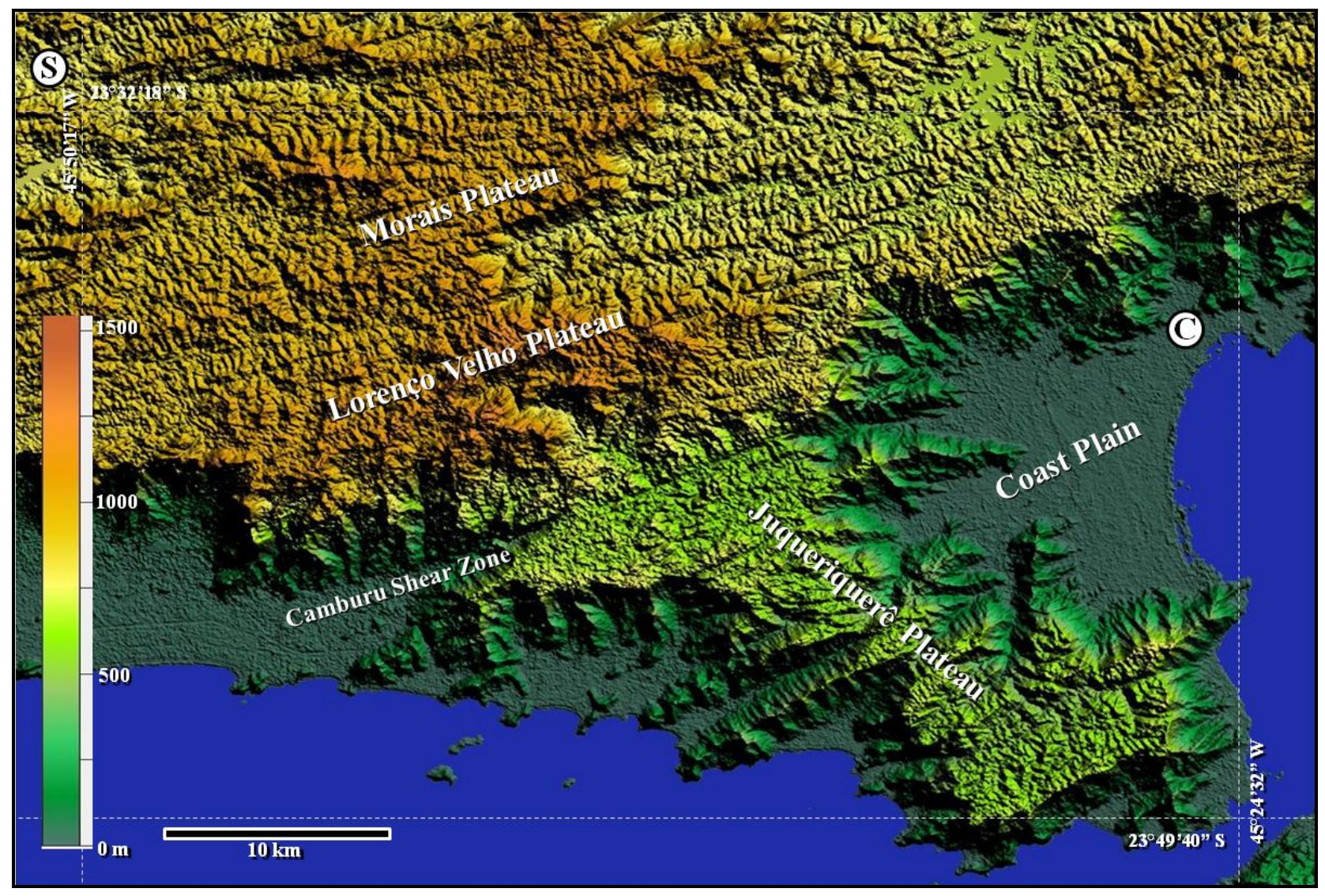

Figure 4. Digital elevation model generated from the SRTM data (IUGS) displaying the main morphological domains of the SCT region. The letters $\mathrm{S}$ and $\mathrm{C}$ as in Figure 1.

elements and valorisation of geoheritage sites". In the first case, the quality of the aesthetic appearance and rarity prevail widely, whereas in the second, the decision is mainly taken on the basis of scientific criterion. A proposal that seeks unifying those two concepts was separately suggested by Dowling [31] and Crawfo and Black [32]. For these authors, besides the importance of exploring the Earth geological features without degrading the nature elements, geotourism is an activity that brings an economic benefit locally and generates tourist satisfaction. On the basis of these new proposals were selected eight different sites (Figure 5), which will be described to follow.

\subsection{Tietê Headwaters Park (SCT-01)}

The Tietê River has its spring in the Serra do Mar, at 96 $\mathrm{km}$ from the São Paulo city centre, in Salesópolis district. Although the source lies only at $22 \mathrm{~km}$ away from the ocean, the watercourse of the Tietê River, with a NW-SE direction and $1.100 \mathrm{~km}$ in length, runs for the interior of the continent up to discharge its waters into the Paraná River (Figure 6) [33]. An extensive historical review about the Tietê River was carried out by Medaglia and
Cunha [34], analyzing various aspects from the time of its discovery until the current.

The Commission of the Brazilian Geography Society delimited in 1954 the place of the Tietê River spring and, four decades later, over an area of $1.340 \mathrm{~km}^{2}$ covered by the Atlantic Forest, was created the Tietê Headwaters Park for preserving the recharge source area. At the local where the headstream is situated, the water arises by a fracture system of the basement rocks, which has become the main attraction of the park. In addition to the source, this natural area also provides four educative trails and an iconographic museum that illustrates the different aspects of the river. Unquestionably, these resources have been proven effective for the environmental education practice. The Tietê Headwaters Park receives each year a little more than 24,000 people, including students, teachers and other types of visitors that aim a leisure activity [33].

\subsection{Spheroidal Weathering and Unusual Shape Blocks (SCT-02)}

The rounded shape in rock bodies is strongly influenced by the mechanical and chemical weathering processes [35]. The fracture system begins cutting the rocks in an- 

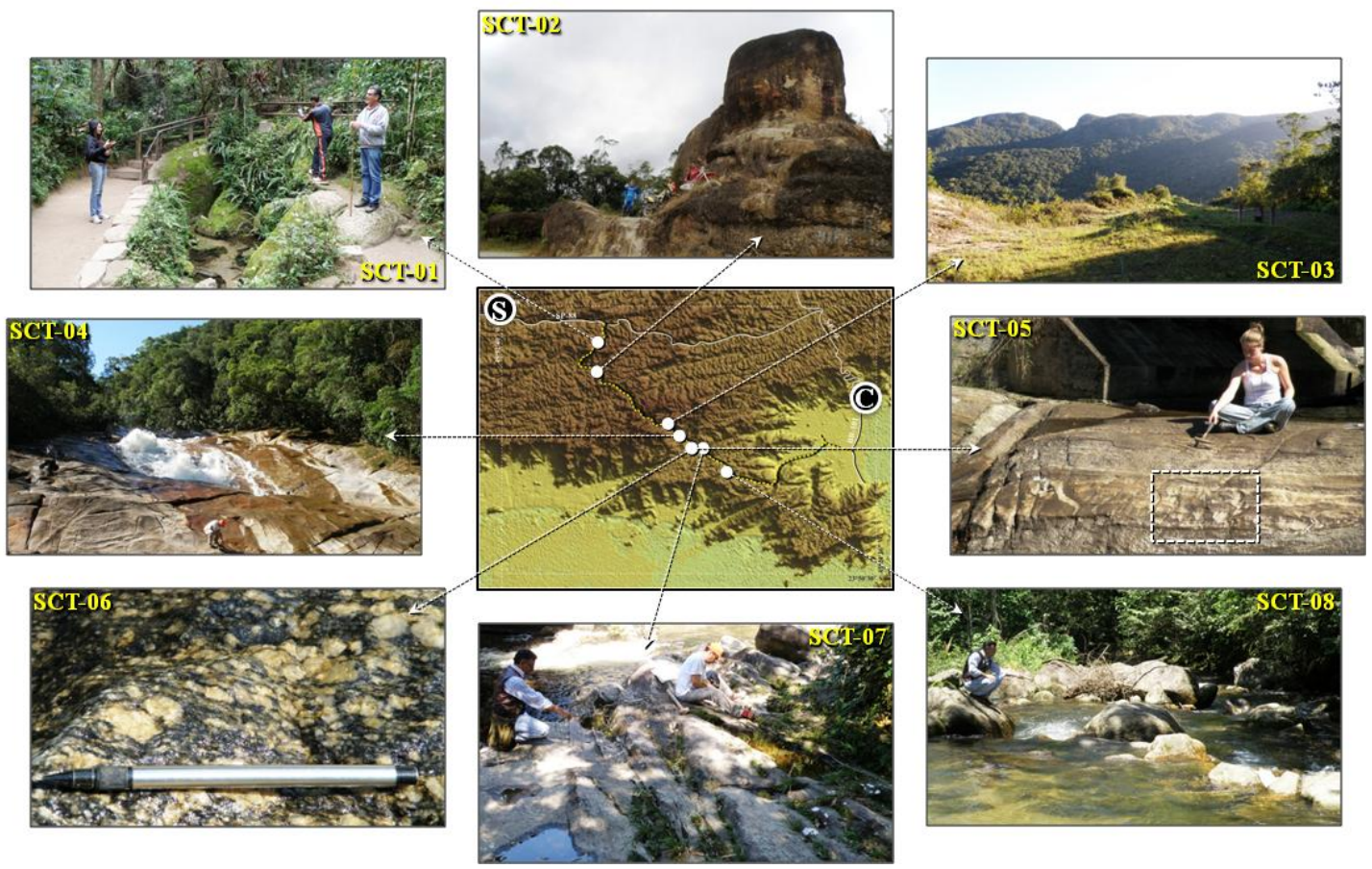

Figure 5. Location of the sites catalogued along the SCT of high potentiality for geotourism. The dashed box in the SCT-05 image indicates the area magnified in Figure 7. The letters $S$ and $C$ as in Figure 1.

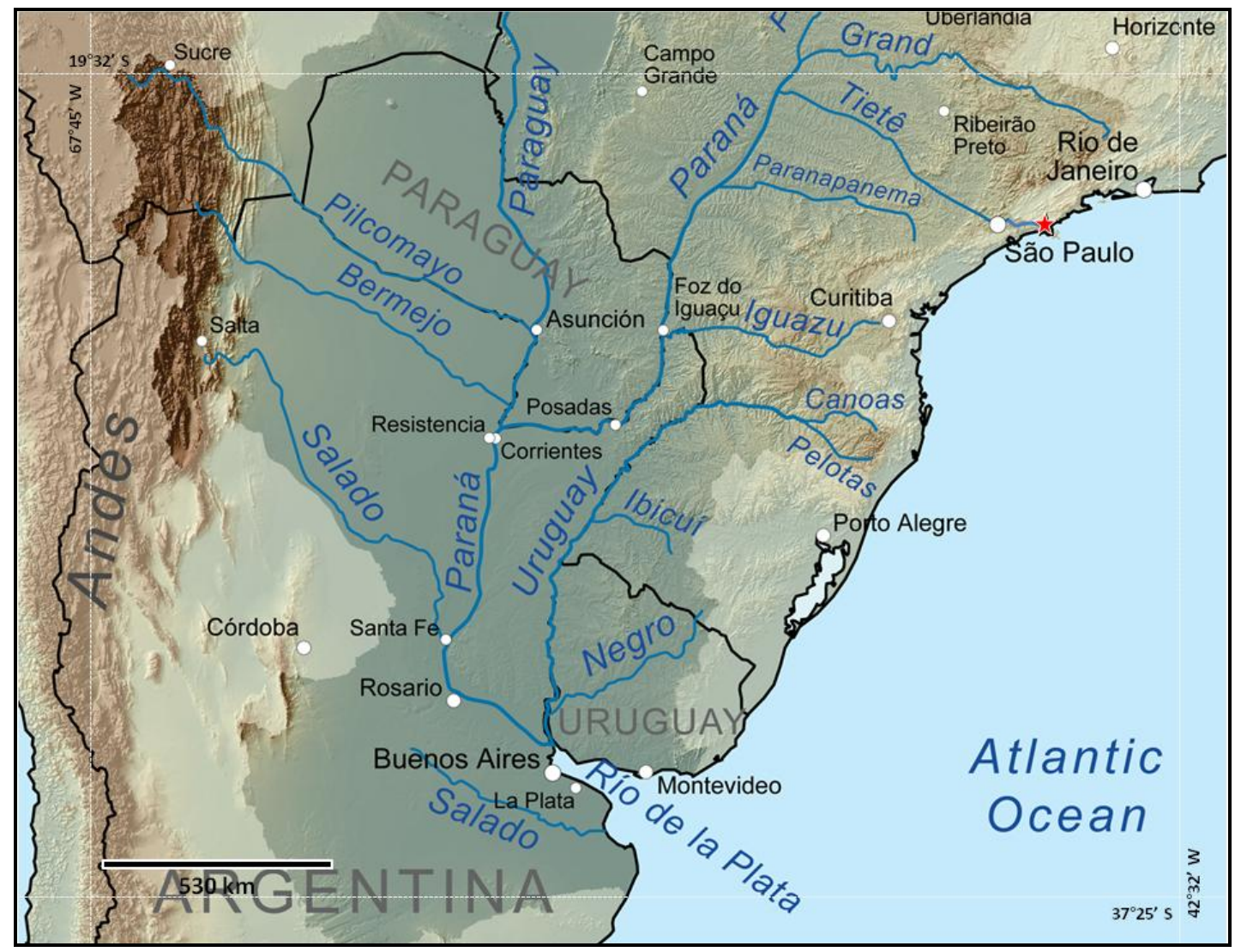

Figure 6. Schematic map showing the Tietê River flowing from Salesópolis (red star) towards the Paraná River (modified from the Wikipedia free encyclopedia). 
gular blocks, increasing considerably the percolation of fluids. The dissolution of the minerals is given on the corners and along the surface of fractures of the blocks. The disaggregated material is removed by the erosion, and the original blocks lose the corners, edge, and mainly volume. In this processes, each fragment is gradually modified to the rounded shape.

The vast majority of the granite and granite gneiss that outcrop in the region displays a distinctive spheroidal weathering. The first minerals to be dissolved are those with a high concentration of iron and magnesium in the composition (biotite and amphibole), followed almost immediately by feldspars. The quartz, a very resistant mineral to the chemical dissolution, is removed at a later stage by a mechanical breakdown. The single boulder is mostly composed of clay minerals and quartz grain aggregates. However, at the cores of the large boulders, relatively fresh rock may be preserved. Many boulders are 5 to $10 \mathrm{~m}$ in diameter and represent true monuments in the landscape.

\subsection{Japi Planation Surface (SCT-03)}

As proposed by Almeida and Carneiro [23], the Japi Planation Surface is a regional geomorphological feature constituted of hills with tops flattened by the action of erosion, perceptible over the entire surface of the Precambrian terrain in the Brazilian south-eastern region [28], which has been influenced by the combination of taphrogenesis, shearing and gravitational faulting during the Cenozoic ( $\sim 5 \mathrm{Ma}$ ) [36]. Between the most startling landscapes, the planation surface is markedly noticeable in the Juqueriquerê, Lorenço Velho and Morais plateaus. The plane of reference, defined by the tops flattened of hills and ridges of gentle undulation over the horizon, clearly indicates the level of the erosive process that has sculpted the basement rocks of variable resistance. These places provide a formidable panoramic view to the practice of landscape photography. Waterfall, river and deep valley are some of the attractions that make up the scenery.

\subsection{Juqueriquerê River Waterfall (SCT-04)}

The spring of the Juqueriquerê River is located in the Lorenço Velho Plateau, at an altitude of roughly $1000 \mathrm{~m}$, and flows into the ocean, with a NW-SE general direction, cutting obliquely the regional structures. The river has an approximate length of $40 \mathrm{~km}$, and the channel is an elongated valley installed on different types of rocks that, in terms of textures and structures, are much diversified. In some places, the river runs over a steep slope surface, carving spectacular falls through the underlying metamorphic rocks, and becomes a site extremely attrac- tive, with tremendous amounts of water cascading. The waterfalls offer a singular natural environment surrounded by the Atlantic Forest whereas the shear zone, minor folding, foliation and complex banding, present in the igneous and metamorphic basement rocks, provide evidence of a typical geological setting of convergent plate movements that have occurred during the assemblage of the Western Gondwana supercontinent.

\subsection{Percussion Fractures in Boulder (SCT-05)}

The marks of percussion fractures that occur in fluvial boulder can be used to identify bedrock fluvial systems in regions of natural degradation of landscape [37]. In steep upstream, the large boulders usually enter the fluvial system through the canyon walls, toppling, avalanche or landslide, might also be the remnant load of a higher magnitude regime of palaeoflow [38]. In all these cases, the sediment transport system is a particularly favorable condition for a collision at high speed between clasts. As a consequence of crushing between larger stones, several specific features are formed on the polished surface of the clasts, which include rounding, polishing, smoothing, fracturing, percussion-fracture facet, percussion-fracture ridges, and bulb of percussion, radial fissure, undulation, hertzian cone, incipient cone, and termination $[37,38]$. Some of these features were observed on the surface of the metamorphic rock boulders, ranging from $0.5 \mathrm{~m}$ to 3 $\mathrm{m}$ in size, that occur along the Juqueriquerê River channel. The blocks display a polished surface, free from corners, and flaking reddening weathering. Several smaller precussion fractures are overlapping on the surface of the blocks (Figure 7).

\subsection{Granular Disintegration in Granite Gneiss Rocks (SCT-06)}

Granular disintegration is a combined process, involving

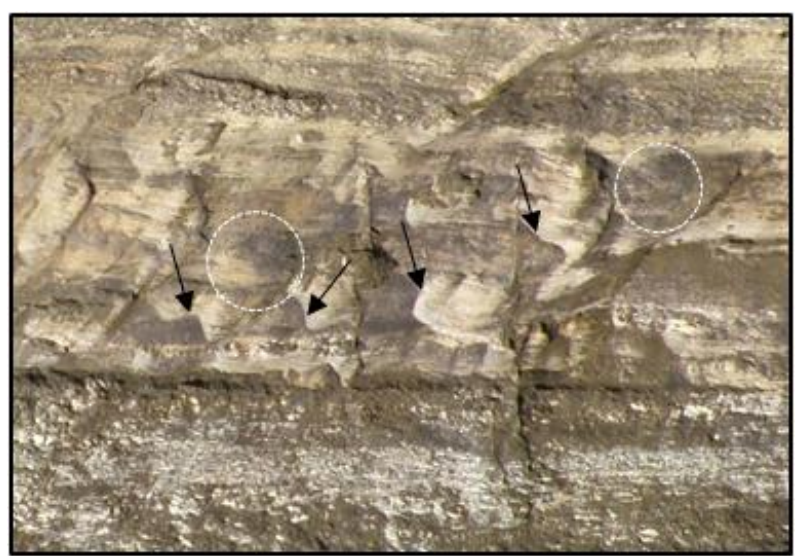

Figure 7. Percussion fracture ridges (distal), narrows, and buld of percussion, circles. Refer to Figure 5 for location. 
physical and chemical weathering, that acts on the rock surface leading the minerals to break up grain-to-grain [39]. The phenomenon is most common in coarse-grained and poly-mineral rocks [38].

A very similar feature was recognized on the surface of weakly foliated augen granite gneiss. Mafic minerals (biotite/amphibole) are interlayered with large lenticular grains or granular aggregates of k-feldspar. As the mafic constituents are much more susceptible, the product of weathering results in a roughened surface highlighting the augen of the k-feldspar megacrystals.

\subsection{Mylonitic Foliation Surface (SCT-07)}

Mylonite is a very fine grained metamorphic rock formed by ductile deformation during intense shearing. The constituent minerals of the protolith are severely crunched and a new crystallographic fabric and textural pattern with a noticeable foliation, entirely different from the original rock, is development [40]. As a result of the dynamic recrystallization, in high P-T conditions, the minerals are arranged along of the foliation plane, which are preferentially oriented parallel to the main stress [41].

The Camburu Shear Zone is characterised by a long strip of mylonitic foliation [20] that separates two morphostructural units, Lorenço Velho Plateau, to NW, and Juqueriquerê Plateau, to SE (Figure 4). This shear zone was developed in basement granite gneiss, and the rocks show commonly textures ranging from protomylonite to ultramylonite [20]. The outcropping is an exceptional exposition that provides a particular opportunity to understand the metamorphic processes that involve during the mylonitic rocks formation. Penetrative foliation, anastomosing cleavage and segregation of minerals, as a result of the recrystallization, are the most common features in mylonitic fabric. These deformation features are highlighted by the stream water and may be promptly observed on the rock surface.

\subsection{Fluvial Boulders Landscape (SCT-08)}

The rivers have, regardless of size, the same basic function: transporting water and sediments, both organic and inorganic materials, from a region topographically highest to another of lowest altitude, and finally culminating its course into the ocean or a lake [42]. The bedrock fluvial system is generally different from alluvial systems. A bedrock channel is commonly characterised by boulder deposits that were accumulated during an extreme turbulence flow from upstream source areas [43]. The very coarse sediments also can be incorporated in the channel through lateral hillslope connection, debris flows and landslides [44].

Alongside the Juqueriquerê River may be found de- posits isolated of boulders, essentially of metamorphic rocks, that display different forms. On the lowest slope surface, the boulders are longitudinally aligned with the stream flow, appearing as undulations in the channel. The place is particularly interesting to explore other processes of physical erosion and sediment transport capacity in bedrock fluvial systems, which are extraordinarily efficient for removing cobbles and boulders from the bedrock channel.

\section{Final Considerations}

In several segments of the SCT is possible to apply one of the most relevant principles in geoscience to understand in an effective manner the landscape evolution: the dynamic interaction between tectonic, lithology, climate, and erosion.

In geological terms, the region reveals a noticeable difference between the basement lithological units, the magmatic intrusion types and the different periods of tectonic events. From the geomorphological viewpoint, a large part of the trail is characterised by a landform composed of hills with steep scarps and tops flattened, which belong to the Serra do Mar orogenic system. Nevertheless, in the final stretch, there is a clear domain of coastal plain. The superficial drainage pattern is controlled by the basement rock structures, as well as by the regional tectonic setting. In some places, steep slopes and small valleys unite in a singular shape forming a small watershed with an outstanding panoramic view. Other particularities worth mentioning are the structures that were formed by the weathering and erosion action on igneous and metamorphic rocks. The spheroidal weathering, massive bedrock and balancing boulders are the most frequent.

The geosites were not simply catalogued with the intention of showing the different styles of leisure activity that can develop the visitors. From the environmental preservation viewpoint, the set of data collected is devoted for a broad group of professionals that comes focusing its activities in diverse sectors of the education, management of parks, tourist guide, and even up for the companies more compromised with the sustainable tourism. The outcrops are accompanied of an alphanumeric identification, location map, and a description in order to make it easier the identification of the geological features in each site. This form of approach should stimulate the professionals to improve their own conception about the value of the nature, their performance with instructor, as well as their active participation in the preservation of the geological records.

In these times of heightened environmental awareness, understanding the geological processes that have shaped each relief of terrestrial surface is essential for predicting 
how the present similar transformations may influence our lifetime in the future. In this way, from a seeming stability of the igneous and metamorphic rock blocks to the dynamic coastal environments, the trial reveals an unending source of information for reconstituting the evolution of a long and complex geological history. In the broader context, those outcroppings enable to visualize the close relationship between rock, climate, topography and the types of soil, which in turn exert strong controls on the diversity of species animals and vegetables. Therefore, preserving these geological records, which have been moulded over hundreds millions of years, is absolutely necessary.

Finally, the SCT has stunning scenery for the development of geotourism, including valleys, streams, waterfalls and the unusual shapes of rocks. Likewise, the visitors will have opportunities of appreciating the spring of the Tietê River, as well as to make physical activity of moderate intensity (walking, bicycling), adventure sport, off-road, and landscape photography. It should be mentioned also that all this diversity of attraction is situated a little more than $130 \mathrm{~km}$ from the São Paulo city, the most populous metropolis in the southern hemisphere.

\section{Acknowledgements}

This paper could not have been produced without the significant efforts of several individuals and organizations. We extend our sincerest appreciation and thanks to all who contributed, in particular, to Gastão Gonçalves, Director of the Tietê Headwaters Park, Program Project 1 of the University of São Paulo, and Geologic Institute of the SMA/SP.

\section{REFERENCES}

[1] R. K. Dowling, "The Emergence of Geotourism and Geoparks,” Journal of Tourism, Vol. 9, No. 2, 2008, pp. 227236.

[2] T. A. Hose, "Selling the Story of Britain's Stone," Environmental Interpretation, Vol. 10, No. 2, 1995, pp. 16-17.

[3] D. Newsome and R. K. Dowling, "Geotourism: The Tourism of Geology and Landscape,” Good Fellow Publishers, Oxford, 2010.

[4] D. Newsome, R. K. Dowling and Y. F. Leung, "The Nature and Management of Geotourism: A Case Study of Two Established Iconic Geotourism Destinations,” Tourism Management Perspectives, Vol. 2, No. 3, 2012, pp. 19-27. http://dx.doi.org/10.1016/j.tmp.2011.12.009

[5] M. A. J. S. Plestch, V. F. Velázquez, J. M. Azevdo Sobrinho, A. C. M. Guedes and G. Zobbel, "The Geodiversity of the Salesópolis-Caraguatatuba Trail and Its Potentiality for the Development of Nature Tourism," 46th Congresso Brasileiro de Geologia, Santos, 30 - September-5 October 2012, CD-ROM.
[6] INPE, “Atlas dos Remanescentes Florestais da Mata Atlântica,” No Período de 2011 a 2012. http://www.inpe.br/noticias/noticia.php?Cod_Noticia=32 99

[7] F. F. M. Almeida, G. Amaral, U. G. Cordani, K. Kawashita, "The Precambrian Evolution of the South American Cratonic Margin South of Amazonas River,” In: A. E. M. Nairn and F. G. Stehli, Eds., The Ocean Basin and Margins, Plenum Press, New York, 1973. pp. 411-446.

[8] U. G. Cordani, B. B. Brito-Neves and M. S. D’Agrella, "From Rodinia to Gondwana: A Review of the Available Evidence from South America," Gondwana Research, Vol. 6, No. 1, 2003, pp. 275-284. http://dx.doi.org/10.1016/S1342-937X(05)70976-X

[9] M. Heilbron, C. M. Valeriano, C. C. G. Tassinari, J. C. H. Almeida, M. Tupinambá, O. Siga Jr. and R. J. A. Trouw, "Correlation of Neoproterozoic Terranes between the Ribeira Belt, SE Brazil and Its African Counterpart: Comparative Tectonic Evolution and Open Questions,” In: R. J. Pankhurst, R. A. J. Trouw, B. B. Brito Neves and M. J. Wit, Eds., West Gondwana Pre-Cenozoic Correlations across the South Atlantic Region, 294, The Geological Society of London, London, 2008, pp. 211-237.

[10] C. C. G. Tassinari, J. M. U. Munha, C. M. Dias Neto, T. B. Santos, U. J. Cordani, A. P. Nutman and P. T. Fonseca, "Constrains on the Thermochronological Evolution of Ribeira Fold Belt, SE Brazil: Evidence for Long-Term Elevated Geothermal Gradient of Neoproterozoic Orogenies," V South American Simposium on Isotope Geology, Punta del Leste, Short Papers, Vol. 1, 2006, pp. 200-203.

[11] M. S. Morais, "Integração Geológica da Folha SantosSF.23-Y-D,” Escala 1:250.000, Companhia de Pesquisa de Recursos Minerais, São Paulo, 1999, p. 26.

[12] C. L. Passarelli, “Caracterização Estrutural e Geocronológica dos Domínios Tectônicos da Porção Sul-Oriental do Estado de São Paulo,” PhD Dissertation, Instituto de Geociências, Universidade de São Paulo, São Paulo, 2001.

[13] C. M. Dias Neto, "Evolução Tectono-Termal do Complexo Costeiro (Faixa de Dobramentos Ribeira) em São Paulo,” PhD Dissertation, Instituto de Geociências. Universidade de São Paulo, 2001.

[14] M. M. Perrota, E. D. Salvador, R. C. Lopes, L. Z. D’Aggostino, N. G. Peruffo, S. D. Gomes and J. V. Lacerda Filho, "Mapa Geológico do Estado de São Paulo,” Escala 1:750.000, Mapas ou Similares/Mapa, Cartas, 2005,

[15] C. Q. T. Maffra, “Geologia Estrutural do Embasamento Cristalino na Região de São Sebastião, SP: Evidências de um Domínio Transpressivo,” MSc Dissertation, Instituto de Geociências, Universidade de São Paulo, 2000.

[16] V. A. Janasi and H. H. G. J. Ulbrich, "Inventário Bibliográfico de Granitos do Estado de São Paulo,” Boletim Instituto de Geociências, Vol. 11, No. Esp., 1992, p. 253.

[17] A. J. Fernandes, “Complexo Embu no Leste do Estado de São Paulo: Contribuição ao Conhecimento da Litoestratigrafia e da Evolução Estrutural e Metamórfica," 
MSc Dissertation, Instituto de Geociências, Universidade de São Paulo, São Paulo, 1991.

[18] M. G. Silva, “Evidências Isotópicas e Geocronológicas de um Fenônemo de Acrescimento Crustal Transamazônico no Gráton do São Francisco, Estado da Bahia,” Sociedade Brasileira de Geologia, Congresso Brasileiro de Geologia, 37, São Paulo, Resumos Expandidos, Vol. 2, 1992, pp. 181-182.

[19] A. T. S. F. Silva, C. Chiodi Filho, D. K. Chiodi and W. D. Pinho Filho, "Projeto Santos-Iguape: Relatório Final," Companhia de Pesquisa de Recursos Minerais, Vol. 1, 1977, p. 641.

[20] G. A. C. Campanha, H. H. Ens and W. L. Ponçano, "Análise Morfotectônica do Planalto do Juqueriquerê, São Sebastião,” Revista Brasileira de Geociências, Vol. 24, No. 1, 1994, pp. 32-42.

[21] C. M. Dias Neto, C. T. Correia, C. C. G. Tassinari and J. M. U. Munhá, "Os Anfibolitos do Complexo Costeiro na Região de São Sebastião, SP,” Geologia USP, Série Científica, Vol. 9, No. 3, 2009, pp. 71-87.

[22] F. F. M. Almeida, "The System of Continental Rifting Bordering the Santos Basin,” Anais de Academia Brasileira de Ciências, Vol. 41, No. 2, 1976, pp. 15-26.

[23] F. F. M. Almeida and C. D. R. Carneiro, "Origem e Evolução da Serra do Mar," Revista Brasileira de Geociências, Vol. 28, No. 2, 1998, pp. 135-150.

[24] F. F. M. Almeida, "Fundamentos Geológicos do Relevo Paulista,” Boletim do Instituto Geográfico e Geológico, Vol. 41, No. 3, 1964, pp. 169-263.

[25] W. L. Ponçano, C. D. R. Carneiro, C. A. Bistrichi, F. F. M. Almeida and F. L. Prandini, "Mapa Geomorfológico do Estado de São Paulo,” Instituto de Pesquisas Tecnológicas, São Paulo, 1981, p. 94.

[26] W. L. Ponçano and F. F. M. Almeida, "Superfícies Erosivas nos Planaltos Cristalinos do Leste Paulista e Adjacências: Uma Revisão,” Cadernos IG/UNICAMP, Vol. 3, No. 1, 1993, pp. 55-90.

[27] L. K. Tonizagua, "Análise Morfológica das Vertentes da Serra do Juqueriquerê em São Sebastião-SP," MSc Dissertation, Instituto de Geociências, Universidade de São Paulo, São Paulo, 2000.

[28] P. V. Zalán and J. A. B. de Oliveira, “Origem e Evolução Estrutural do Sistema de Riftes Cenozóicos do Sudeste do Brasil,” Boletim Geociências Petrobrás, Vol. 13, No. 2, 2005, pp. 269-300.

[29] R. C. Valadão, "Evolução de Longo-Termo do Relevo do Brasil Oriental (Desnudação, Superfícies de Aplanamento e Soerguimentos Crustais)," PhD Dissertation, Instituto de Geociências, Universidade Federal da Bahia, Salvador, 1998.

[30] D. Predrag and D. Mirela, "Inventory of Geoheritage Sites-The Base of Geotourism Development in Montenegro,” Geographica Pannonica, Vol. 14, No. 4, 2010, pp. 126-132.

[31] R. K. Dowling, “Geotourism’s Global Growth,” Geohe- ritage, Vol. 3, No. 1, 2011, pp. 1-13.

[32] K. R. Crawfo and R. Black, "Visitor Understanding of the Geodiversity and the Geoconservation Value of the Giant's Causeway World Heritage Site, Northern Ireland," Geoheritage, Vol. 4, No. 2, 2012, pp. 115-126. http://dx.doi.org/10.1007/s12371-011-0049-6

[33] DAEE, “Parque Nascente do Tietê,” 2011. http://www.daee.sp.gov.br/

[34] T. Medaglia and V. Cunha, “Tietê-Um rio de Várias Faces,” Horizonte, São Paulo, 2009.

[35] W. K. Hamblin and E. H. Christiasen, "Earth’s Dynamic Systems,” 10th Edition, Pearson Prentice Hall, Upper Saddle River, 2010.

[36] C. Riccomini, L. G. Sant’Anna and A. L. Ferrari, "Evolução Geológica do Rift Continental do Sudeste do Brasil,” In: V. Mantesso-Neto, A. Bartorelli, C. D. R. Carneiro and B. B. Brito-Neves, Eds., Geologia do Continente Sul-Americano: Evolução da obra de Fernando Flávio Marques de Almeida, Beca, São Paulo, 2004. pp. 383-405.

[37] K. Richardson, and P. A. Carling, "A Typology of Sculpted Forms in Open Bedrock Channels,” Geological Society of America, Special Papers, 2005, p. 108.

[38] M. C. Bourke and H. A. Viles, "A Photographic Atlas of Rock Breakdown Features in Geomorphic Environments," Planetary Science Institute, Tucson, 2007.

[39] D. T. Nicholson, “Granular Disintegration,” In: A. S. Guide, Ed., Encyclopedia of Geomorphology, Routeledge, London, 2004, pp. 493-494.

[40] B. R. Harker, A. Yin and J. M. Christie, "Differential Stress, Strain Rate, and Temperatures of Mylonitization in the Ruby Mountains, Nevada: Implications for the Rate and Duration of Uplift,” Journal of Geophysical Research, Vol. 95, No. B6, 1990, pp. 8569-8580. http://dx.doi.org/10.1029/JB095iB06p08569

[41] J. L. Urai, W. D. Means and G. S. Lister, "Dynamic Recystallization of Minerals,” Geophysical Monograph Series, Vol. 6, 1986, pp. 161-199. http://dx.doi.org/10.1029/GM036p0161

[42] D. L. Hogan and D. S. Luzi, "Channel Geomorphology: Fluvial Forms, Processes, and Forest Management Effects,” In: R. G. Pike, T. E. Redding, R. D. Moore, R. D. Winker and K. D. Bladon, Eds., Compendium of Forest Hydrology and Geomorphology in British Columbia, Landscape Management Handbook 66, 2010, p. 805.

[43] J. R. Goode and E. Wohl, "Coarse Sediment Transport in a Bedrock Channel with Complex Bed Topography," Water Resources Research, Vol. 46, W11524, 2010, pp. 114.

[44] K. X. Whipple, "Bedrock Rivers and the Geomorphology of Active Orogens," Annual Review of Earth and Planetary Science, Vol. 32, 2004, pp. 151-185. http://dx.doi.org/10.1146/annurev.earth.32.101802.12035 $\underline{6}$ 